\title{
Annotating Aristotle's Organon in the Byzantine Age: Some Remarks on the Manuscripts Princeton MS 173 and Leuven, FDWM 1
}

\begin{abstract}
In the Byzantine world, the activity of annotating the Organon - the collection of six treatises on logic written by Aristotle - was quite a customary practice in learning and teaching activities of educated people since logic was a constitutive part of the standard scholastic curriculum. Byzantine scribes and scholars used to fill the blank spaces in a manuscript with short glosses and excerpts mostly taken from pre-existing commentaries by Late Antique and Byzantine authors. Each manuscript that transmits Aristotle's texts along with annotations reflects the scholarly activities carried out on those texts over centuries. The manuscript Princeton MS 173 of the Princeton University Library is analysed here as a case study. It was produced towards the end of the thirteenth century by a single scribe who copied Aristotle's treatises as well as some commentaries on them placed in the margins. In the fourteenth and fifteenth century, the manuscript was in the possession of scholars who judiciously augmented the exegetical apparatus by inserting glosses and further commentaries. In the present paper, the exegetic activity on Posterior Analytics in this manuscript will be scrutinised and some exemplary passages from Book 2 selected. The interactions between this manuscript and another one now kept in Leuven (KU Leuven Libraries, Special Collections, FDWM 1) will be also investigated.
\end{abstract}

\section{Introduction}

If we consider the surviving manuscript production of the Byzantine age, we will discover that the secular author whose works were most often copied was

Ә Open Access. (๑) 2021 Stefano Valente, published by De Gruyter. (cc) BY-NC-ND This work is licensed under the Creative Commons Attribution-NonCommercial-NoDerivatives 4.0 International License.

https://doi.org/10.1515/9783110741124-010 
Aristotle: over a thousand codices of his works are still preserved. ${ }^{1}$ However, not all of his treatises enjoyed the same popularity throughout the Byzantine millennium. The most widespread Aristotelian treatises were those included in the Organon. This is a structured collection of six works on logic: Categories, On interpretation, Prior Analytics (two books), Posterior Analytics (two books), Topics (eight books) and Sophistical Refutations. ${ }^{2}$ Usually, they were introduced by Porphyry's Isagoge. ${ }^{3}$ It is by no means surprising that these logical treatises were so widespread since they provided the learning and teaching background for standard higher education in Byzantium within both the civil and the religious sphere. In fact, the teaching of Aristotelian logic - essentially based on Categories, On interpretation and the first chapters of the Prior Analytics - was a key part of the trivium together with grammar and rhetoric. ${ }^{4}$ In this context, the practice of commenting was one of the main scholarly activities that every producer and/or user of a manuscript of the Organon undertook.

To this end, Byzantine scholars had a wealth of Late Antique and Byzantine commentaries at their disposal that were usually taken as a starting point for studying the text: they were copied both in autonomous manuscripts and in the blank spaces of manuscripts transmitting Aristotle's treatises. Concerning the latter case, the rich manuscript tradition testifies to the intensive and longlasting practice of commenting and annotating the texts of the Stagirite. The manuscripts can therefore provide us with invaluable clues about scholastic and scholarly activities in the Byzantine world.

The practice of annotating Aristotle's texts by adding extracts from commentaries of various origins has been reviewed by Sofia Kotzabassi in a lucid way $(2002,52)$. As she says,

in some cases the scribes copied the entire text of a commentary; in other cases they preferred to take excerpts from one or more commentaries, which they wrote in the margins of each page or between the lines [see her n. 5: 'in most of these manuscripts the space between the lines is wider than usual so that the scribe could add scholia or glosses above

\footnotetext{
1 See, among others, Oehler 1964; Harlfinger 1971, 40-41 ('in über 1000 griechischen Handschriften - unterschiedlich in Zahl und Zusammenstellung der einzelnen Texte -, die aus dem 9. bis 16. Jh. datieren [...], sind uns die Schriften des Aristoteles erhalten. Aristoteles ist damit der handschriftlich meistvervielfältigte profane griechische Autor; er wird in der Verbreitung durch Manuskripte nur von einigen christlichen Texten und Schriftstellern, z.B. allen voran vom Neuen Testament, von Johannes Chrysostomos und Johannes Damaskenos, erreicht oder übertroffen'); Hunger 1978, 11-15, 25-41.
}

2 See e.g. Malink 2011.

3 See e.g. Barnes 2003, XIX-XXIII.

4 See e.g. Erismann 2017. 
the text']. Rarely do two manuscripts of a text have exactly the same excerpts from the same commentators [see her n. 6: 'sometimes the scribes or scholars who copied them changed the text or compiled different scholia or versions of the commentaries, making it difficult for modern researchers to identify their sources']. Moreover, these medieval manuscripts belonged to a succession of owners, many of whom over the centuries tried to enrich their manuscripts by adding new scholia, which they copied from other manuscripts, often ones borrowed from fellow scholars. So, for instance, it is very common to find in manuscripts dating from the thirteenth century scholia written by several later hands of the fourteenth and fifteenth centuries. These scholia document the intensive use of philosophical manuscripts and the continuing interest in Aristotle during the late Paleologan era.

Kotzabassi (2002, 53-62) exemplifies this process by introducing a manuscript produced around the end of the thirteenth century and now kept at the University Library of Princeton: manuscript 173. It was acquired in 2001. The first modern description of it in a catalogue is from 2010. Literature on this item is therefore quite limited: besides Kotzabassi's seminal paper on the history of this 'new' manuscript (2002), Nikos Agiotis (2016) brought some fundamental aspects to light relating to the use of the manuscript by the Byzantine scholar John Chortasmenos. In particular, he stresses that 'Princeton MS 173 offers [...] the opportunity to study how a Byzantine scholiast would bring together, organize, display and finally refer to the content of different manuscripts' (Agiotis 2016, 435).

As Kotzabassi and Agiotis remark, the multi-layered apparatus of comments on the Aristotelian texts in this manuscript is a fairly typical example of commentarial activity performed by Byzantine scribes and scholars between the end of the thirteenth and the first half of the fifteenth century. The present paper will focus on few relevant aspects of this precious written artefact, concentrating in particular on the apparatus of comments on Posterior Analytics. ${ }^{6}$

\section{Case study: the manuscript Princeton MS 173}

The manuscript Princeton, University Library, Department of Rare Books and Special Collections, MS 173 is a large-format manuscript ( $330 \times 245 \mathrm{~mm}$ in size) produced by a single, anonymous scribe by the end of the thirteenth century, as

5 Kotzabassi and Patterson Ševčenko 2010, 147-149, 150.

6 On Posterior Analytics in Byzantium from the twelfth to fourteenth century, see e.g. Ebbesen 2015, 11-16. 
the writing style reveals. ${ }^{7}$ It is now composed of 164 folios of paper without watermarks and contains four treatises of the Organon with an extensive apparatus of annotations: the treatise On Interpretation opens the manuscript, then Prior Analytics, Posterior Analytics and Topics follow. The latter work is incomplete because the last folios of the original manuscript have been lost. ${ }^{8}$ Because of this loss, it is impossible to say whether the last treatise of the Organon, the Sophistical Refutations, was originally included in the manuscript or not.

The scribe who produced the manuscript used the margins to copy a rich apparatus of comments to the main texts. ${ }^{9}$ Later hands dating to the fourteenth and fifteenth century introduced further explanatory notes in the blank spaces. Some of these hands can be traced back to well-known Byzantine scholars and possibly owners of the manuscript: in particular, Kotzabassi $(2002,55-56)^{10}$ attributed some of these notes to Nikephoros Gregoras (1295-1360), who probably owned the manuscript for a while. ${ }^{11}$

Furthermore, Kotzabassi (2002, 57-62) identified the hand of another important scholar in the Princeton manuscript: John Chortasmenos. He was a notary in the chancery of the Patriarchate in Constantinople and lived between the fourteenth and fifteenth century (c.1370-1430/1). ${ }^{12}$ On fol. $78^{\mathrm{r}}$, where the first book of Posterior Analytics begins, Chortasmenos wrote a personal note

7 The script shows some features typical of the so-called 'beta-gamma style', attested between the last quarter of the thirteenth century and the beginning of the fourteenth century: see Kotzabassi 2002, 53-54 along with n. 10 for further literature; Kotzabassi and Patterson Ševčenko 2010, 148.

8 See Kotzabassi 2002, 54: 'from the collation, we can conjecture that in its original condition the manuscript began as it does today, that is, without Categories, the work with which most of the Organon manuscripts begin'. The first quire number appears at the bottom of fol. $17^{\mathrm{r}}$, but it was probably written by a later hand. The first quire number attributable to the first hand can be discovered on fol. $33^{\mathrm{r}}\left(\varepsilon^{\prime}=5\right)$, as Kotzabassi remarks (2002, 54 n. 12). See also Kotzabassi and Patterson Ševčenko 2010, 148. Furthermore, the absence of Porphyry's Isagoge is also remarkable.

9 He probably reproduced the exegetical apparatus of the manuscript he used as model. As for Posterior Analytics, the same corpus of annotations occurs also in other manuscripts of the Paleologan age, such as the Ambrosiani B 103 sup. and D 82 sup., the Laurentianus pluteus 72,4 and the Bodleianus Baroccianus 177. The study of these manuscripts and their annotations is currently in progress.

10 See also Kotzabassi and Patterson Ševčenko 2010, 148-149.

11 On Nikephoros Gregoras, see e.g. PLP 4443.

12 On this important intellectual figure of the late Byzantine age, see Hunger 1969; RGK I no. 191, II no. 252, III no. 315, PLP 30897. See also Kotzabassi 2002, 57 n. 22 and Cacouros 20172018, 88-90 for further literature. 
between the title of the treatise and the beginning of the main text. The text is particularly relevant, as Kotzabassi pointed out $(2002,58)$. It reads as follows: ${ }^{13}$

By myself, John Chortasmenos, patriarchal notary (...) during the reign of the most pious emperor Manuel Palaiologos [1392-1425] and the patriarchate of the most holy patriarch Matthew [1397-1410] in the year after the battle with the Turks [1402?].

According to the historical data, this autograph note could date to $1403 .{ }^{14} \mathrm{How}$ ever, traces of even earlier activity can be found in another note in the lower margin of fol. 119v. This refers to a passage in the first book of Topics (I 4, 101b28) concerning the difference between 'problem' and 'protasis'. ${ }^{15}$ After the explanation taken from another scholar from the early fourteenth century, Joseph Rhakendytes, ${ }^{16}$ Chortasmenos wrote the following remark: ${ }^{17}$

Our teacher, the first notary (protonotarios), our brother [name erased] $<$ says $>$ that problem and protasis have the same meaning: for he understands the <???> on the basis of both of them.

Leaving aside the problems of interpreting the exact meaning of the second part of the explanation, which depends on the word that should stand for the erased one, it is clear that Chortasmenos recalls an interpretation given by his master here, who was protonotarios at the Patriarchal Chancery in Constantinople. Apparently, his master did not agree with Aristotle, who pointed out the difference between 'problem' and 'protasis'. According to Kotzabassi (2002, 58-59), this anonymous teacher may have been Michael Balsamon, who 'was appointed as protekdikos of the Great Church of Constantinople and professor of dialectic,

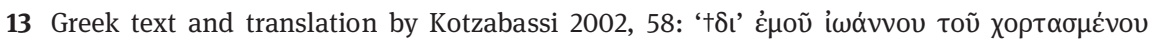

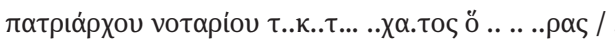
.$\varphi \varphi$ мкі́

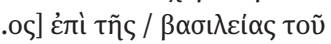

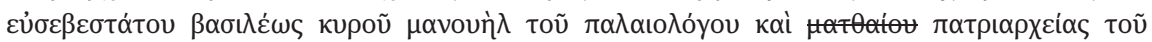

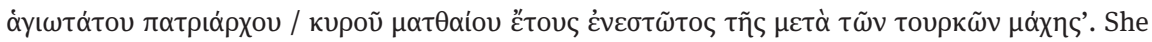
also remarks that 'the first two lines have been struck through in brown ink'.

14 See Hunger 1969, 16; Kotzabassi 2002, 58 n. 24.

15 See. e.g. Brunschwig 1967, 5-6, 118-122; Smith 1997, 59.

16 See Kotzabassi and Patterson Ševčenko 2010, 148 for the text. See also Kotzabassi 2002, 58 n. 25. This quotation may come from Rhakendytes' Synopsis variarum disciplinarum. However, since the Greek text is still unedited, I have not been able to recover it yet. On Rhakendytes, see e.g. Gielen 2016, LXXI-LXXIV with further literature.

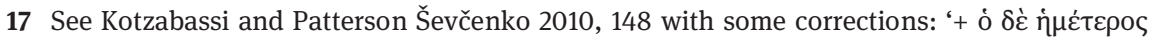

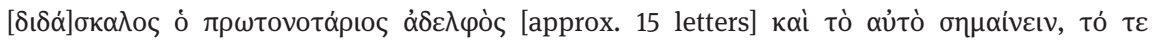

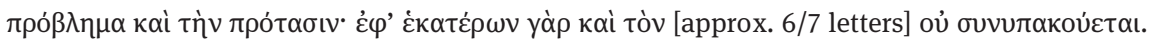
See also Kotzabassi 2002, 58. 
rhetoric, philosophy, and theology by the patriarch Matthew, that is, after 1397; before this appointment, he held the office of protonotarios. Thus, we can assume that the scholion of fol. $118^{\mathrm{v}}$ [immo 119 $]$ was written before 1397'.

Consequently, we can gather some time references for Chortasmenos' scholarly work on this manuscript, which probably began at the very end of the fourteenth century. Since his additions to it were written in inks of various colours, Kotzabassi suggested that his scholarly activity was performed 'at different times'. ${ }^{18}$

Chortasmenos was also a teacher and worked both privately as well as at the Patriarchal school. ${ }^{19}$ His wide range of interests encompassed theology, astronomy and logic in particular. The Princeton manuscript holds some evidence of his scholarly activity on this latter topic. How Chortasmenos came to possess this codex is still not known. ${ }^{20}$

\subsection{John Chortasmenos' use of Princeton MS 173}

We can distinguish three main scholarly activities that Chortasmenos carried out on the texts of the Organon contained in the Princeton manuscript, probably at different times: ${ }^{21}$

1. attribution of the anonymous marginal notes already present in the manuscript to the respective authors, whose names were written in red ink. This implies that Chortasmenos had a library at his disposal where different commentaries on Aristotle's writings were available, thus having the chance to check the references against the sources;

2. addition of annotations and excerpts from further commentaries in the blank spaces. Since some of these notes can be discovered in the deep inner margins, Kotzabassi and Patterson Ševčenko are probably right in saying

18 See Kotzabassi 2002, 59 n. 27: 'Chortasmenos added scholia in the margins of Princeton MS 173 at different times, a hypothesis that is strengthened by the fact that his scholia are written in different colours of ink'.

19 See Hunger 1969, 14-19.

20 However, there was another manuscript in his private library which belonged to Nikephoros Gregoras, viz. the manuscript Vaticanus gr. 1365 with the text of the Astronomy by the Byzantine scholar Theodoros Metochites (1270-1332; see Hunger 1969, 24-25). This codex belonged to the library of the monastery of Chora in Constantinople. It may be that Chortasmenos acquired these two manuscripts together. For recent literature on this manuscript, see the relevant file in the online database Pinakes (https://pinakes.irht.cnrs.fr/ notices/cote/67997/).

21 Not in chronological order. 
that 'it is possible that the manuscript was disbound at the time' $(2010,149)$. This would also explain how Chortasmenos was able to write some entries by turning the page $90^{\circ}$ to the left or right;

3. addition of cross-references: Chortasmenos linked the main text and the marginal comments by using symbols; he sometimes refers to other comments in different parts of the same manuscript by adding more complex symbols; finally, he placed references to another manuscript between the lines of the main text, which only contained commentaries on the Aristotelian treatises.

Some selected examples will now be discussed in order to illustrate the multilayered process of annotating the main text. In particular, I intend to briefly consider Chapter 12 of Posterior Analytics, Book 2. Together with the previous chapter (11), this also deals with the discussion of the notion of 'cause' (aitía, aití $\alpha$ ) as a middle term within a syllogism in relation to time. ${ }^{22}$ In the Princeton manuscript, Chapter 12 begins on line 14 of fol. $111^{\mathrm{r}}$ (see Fig. 1):

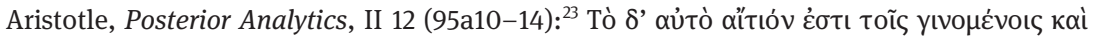

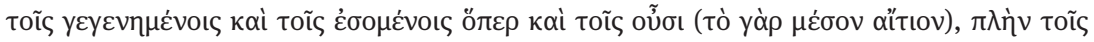

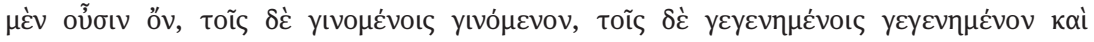

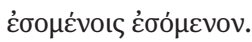

What explains why something is coming about (and why it has come about, and why it will be) is the same as what explains why this is the case: it is the middle term which is explanatory. But if something is the case, the explanatory item is the case; if it is coming about, it is coming about; if it has come about, it has come about; and if it will be, it will be. ${ }^{24}$

In the adjacent right and lower margin, the main scribe added some anonymous explanations on Aristotle's text without linking them to the respective passages (see Fig. 1). The excerpts are only separated from one another by a punctuation mark (':-') and a blank space. Furthermore, the scribe did not add any comment between the lines.

22 See, among others, Ross 1949, 648-653; Barnes 1975, 223-229; Detel 1993, II, 717-738, esp. 717: 'In Kapitel 12 setzt Aristoteles die Diskussion des Ursachenbegriffes in Demonstrationen fort, die in II 11 begonnen hatte, und zwar mit Erwägungen zum zeitlichen Verhältnis von Ursache und Verursachten (“Wirkung”)'; Barnes 1993, 233-240.

23 Here and below, I quote from the edition by Ross 1949.

24 Translation by Barnes 1993, 61. 
Chortasmenos acted in this way: he marked the beginning of the chapter by a punctuation mark in red ink (':') and added the name of the author of the excerpted commentary in the margin: in this case, he wrote 'of Philoponus' ( Фıлолóvou). Then, he cross-referenced the individual comments on the respective sentences in the main text by using symbols in red-ink, both between the lines of the main text and in the blank space before the commentary: concerning the sentence of Posterior Analytics quoted above, we find the symbol ' $\uparrow$ ' in both places. The text of this comment reads as follows: ${ }^{25}$

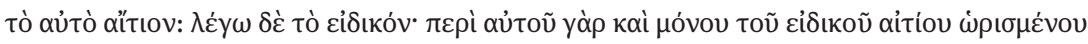

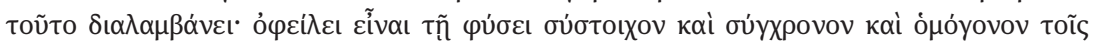

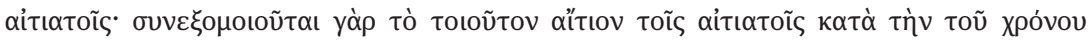
$\tau \rho \mu \varepsilon \dot{\rho \varepsilon} \iota \alpha v^{--}$

The same thing (is) cause: I mean the formal cause. For he [i.e. Aristotle] makes this distinction in relation to this which is the only one to be defined as formal cause. (This cause) has to belong by nature to the same series, time, and genus as the effects. For such a cause is assimilated to the effects according to the tripartition of time.

It should be remarked that this and other excerpts copied by the main scribe in the margins of Posterior Analytics, which Chortasmenos later attributed to Philoponus, have not yet been edited. In Commentaria in Aristotelem Graeca $(C A G)$, a series published by the Academy of the Sciences in Berlin, Volume 13 contains the edition of Philoponus' commentary on Posterior Analytics (Wallies 1909). Regarding the second Book, the excerpts in the Princeton manuscripts do not coincide with those printed there (Wallies 1909, 334-440). However, the authorship of the commentary on the second Book is controversial, as the author is likely to be the twelfth-century scholar Leon Magentinos. ${ }^{26}$ Thus, the Princeton manuscript may be a valuable source for recovering the lost text of Philoponus' commentary.

After cross-referencing the text and the pre-existing commentary, Chortasmenos undertook the task of enhancing the exegetic apparatus of the Princeton manuscript. First of all, he wrote some short exegetic glosses in

25 The orthography and the punctuation have been standardised.

26 See Ebbesen 1981, I, 302-313; Ebbesen 2015, 13 with n. 4. See also Goldin 2009, 1-4, who suspects that this is 'a largely paraphrastic condensation of either a lost commentary on An. Post. 2 by Philoponus, or of another commentary on this book that derives from the lectures of Ammonius. (...) Nonetheless, the matter of authorship and the ultimate source of this material remains highly uncertain' (p. 4). Recent investigations have shown how Magentinos' commentary fairly re-worked Philoponus' materials: see Brockmann 2020; Valente 2021. 
brownish ink between the lines to explain some phrases which may otherwise have been considered ambiguous. For instance, in the opening sentence of Chapter 12 mentioned above, we can find the following glosses above the line:

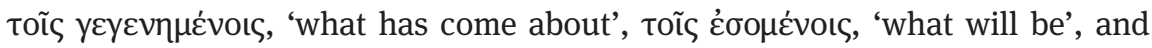

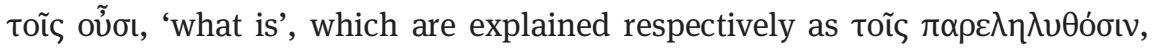

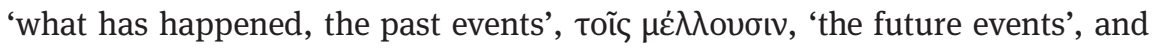

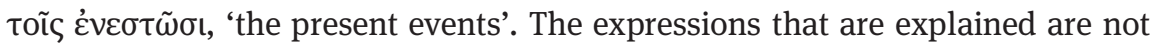
particularly difficult to understand, but Chortasmenos clearly wanted to point out their implicit meaning in the context used here. In this case, the focus is on the constant relationship between a given cause and a given effect in the present, in the past and in the future. The explanation is therefore necessary, particularly in an educational context. These short glosses may have been a sort of aide-mémoire that Chortasmenos could have used in his teaching activity in order to remember the need to explain such words to his students. Similar glosses can be found all over the manuscript.

After having added these glosses to explain the opening sentence of Chapter 12, Chortasmenos copied some excerpts from another commentary in the blank space between the lines. Such additions in brown ink were made when the short glosses had already been written, as the layout of the commentary reveals: above the beginning of the chapter, the commentary was written in a column; the third line runs up to the right margin below the glosses. Chortasmenos then turned the page $90^{\circ}$ to continue the copy between the text and the commentary in the margin. Finally, he wrote the last sentence between the last line of the main text and the commentary at the bottom of the page. A red line links the last sentence to the previous one. As for the content of the exegesis, the text reads as follows:

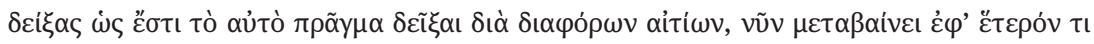

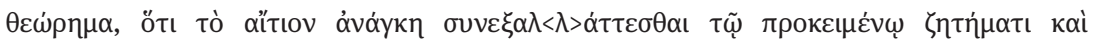

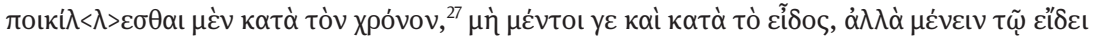

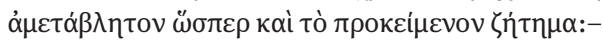

Having proven that it is possible to prove the same thing by means of different causes, he (i.e. Aristotle) now turns to another topic: that the cause and the proposed object of investigation must change together and show variation in regard to time, but not so in respect

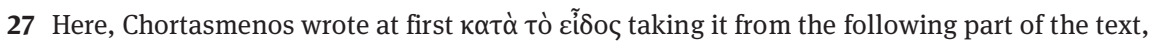
but he immediately acknowledged the mistake and corrected it deleting tò cĩ $\delta$ oc. 
to kind; rather [the cause] must remain unchanged in kind, as does the proposed object of investigation..$^{28}$

The anonymous text does not stem from the pen of Chortasmenos himself, since it coincides with the commentary on the second book that is attributed to Philoponus in Maximilian Wallies' edition. ${ }^{29}$ A comparison with the printed text shows that Chortasmenos only copied a small part of it, namely the first five lines. ${ }^{30}$

In the Princeton manuscript, the text of Chapter 12 of Posterior Analytics, Book 2, continues on the next verso. Here, we discover further aspects concerning the scholarly activity that Chortasmenos performed. In the blank space in the upper left corner of fol. 111 (Fig. 2), he drew the schema of a syllogism Aristotle used to explain the opening sentence of this chapter:

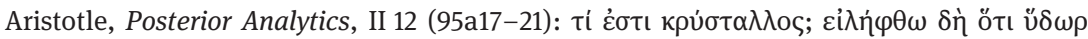

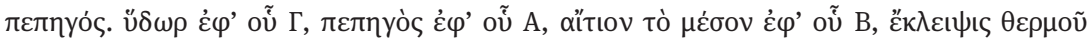

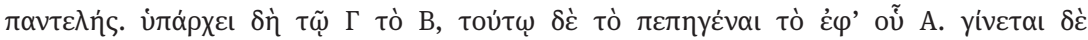

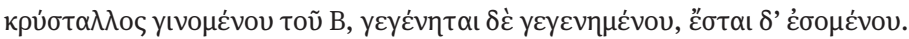

What is ice? - Assume that it is solidified water. Water $C$, solidified $A$; the explanatory middle term is $B$, complete absence of heat. Thus $B$ holds of $C$; and being solidified, $A$

28 Transl. Goldin 2009, 78 with changes.

29 See above, p. 198.

30 Wallies 1909, 386.2-6 (with minor changes); the rest of the full text reads (Wallies 1909,

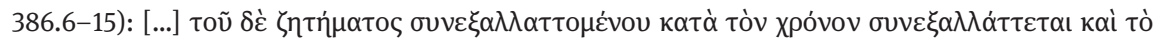

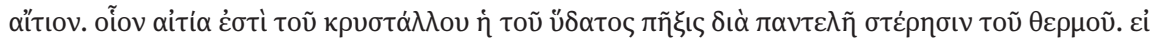

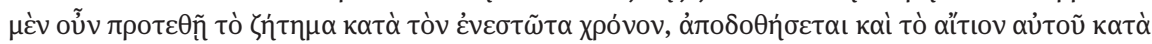

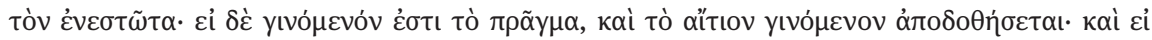

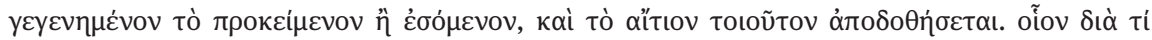

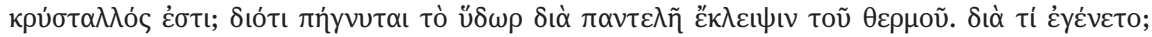

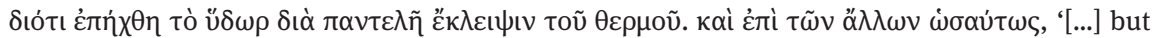
when the object of investigation changes in respect to time the cause too changes with it. For example, the cause of ice is the solidification of the water that comes from total depletion of heat. Now if one were to propose the object of investigation by reference to it in the present tense, its cause too will be rendered in the present. And if the fact is coming to be, the cause too in each case will be rendered similarly. And if that which is proposed is past or future, the cause too will be rendered as this sort of thing. For example, why does ice exist? Because water is solidified on account of the total disappearance of heat. Why did it come to be? Because the water became solidified on account of its total disappearance of heat, and likewise in the other cases' (transl. Goldin 2009, 78). 
holds of $B$. Ice is coming about if $B$ is coming about; it has to come about if has come about; and it will be if it will be. ${ }^{31}$

In the upper margin on the right, the main scribe had already drawn the diagrams of two syllogisms which are now quite faded..$^{32}$ Moreover, the left one does not reflect the exact order of the main text. Thus, Chortasmenos provided a new drawing:

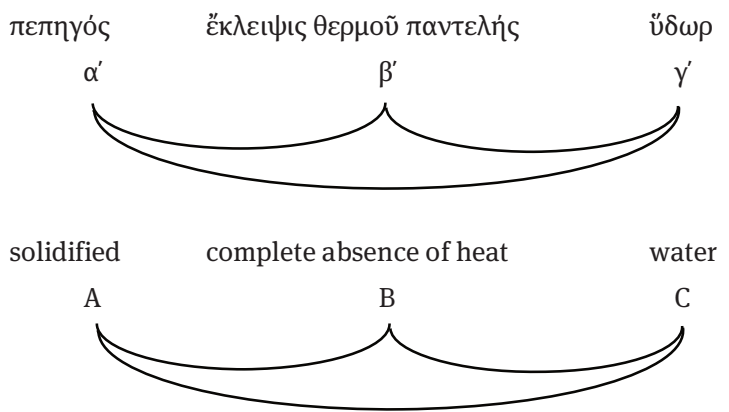

After this syllogism, Aristotle discusses a further topic: the chronological coexistence of cause and effect. Chortasmenos marked this transition by inserting a dicolon in red ink (' $:$ '), just like at the beginning of Chapter $12 .^{33}$ The next sentence of Aristotle's treatise reads as follows (95a22-24):

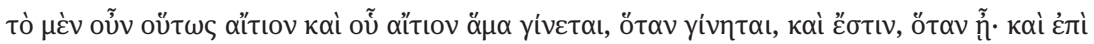

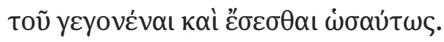

When an item is explanatory in this way and the item of which it is explanatory comes about, then they both come about at the same time; when they are the case, they are the case at the same time; and similarly for 'have come about' and for 'will be'. ${ }^{34}$

In the procedure just described, Chortasmenos wrote some short explanatory glosses between the lines. Then, he used symbols in red ink to link the main text (Fig. 2, line 5) to the existing commentary in the right and lower margin (in this case, something like ' $\dot{Y}$ ') (Fig. 2, line 9). The author of the commentary is

31 Transl. Barnes 1993, 61.

32 On diagrams in Aristotle's manuscripts, see e.g. Bülow-Jacobsen and Ebbesen 1982, 50-52; Panizza 1999; Cacouros 2001; Prapa 2012; Rambourg 2012.

33 See above, p. 197.

34 Transl. Barnes 1993, 61. 
identified as Philoponus: Chortasmenos appended his name in red ink both at the beginning of these excerpts (тои̃ Фı入ото́vov, 'of Philoponus') and, more

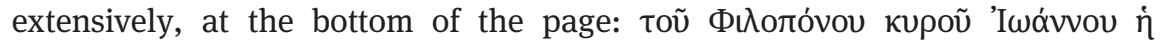

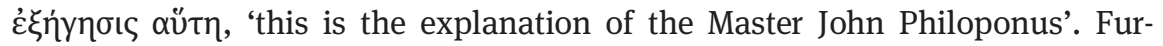
thermore, in the right margin of the commentary, rotated by $90^{\circ}$, Chortasmenos

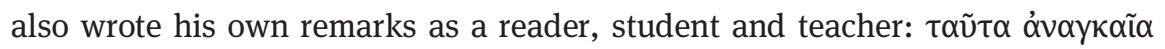
róvv, 'all these (comments) are absolutely indispensable'. This attests once again to the scholar's intensive engagement with the Princeton manuscript and its Aristotelian corpus.

In some other cases, Chortasmenos inserted cross-references to other passages within the manuscript itself in order to establish connections between the comments on different treatises. This is what happens in the right margin of fol. $38^{\mathrm{r}}$ (Fig. 3), for instance. Chortasmenos wrote the following note in red ink toward the end of Chapter 22 of Prior Analytics (40b16) concerning the hypothetical syllogism:

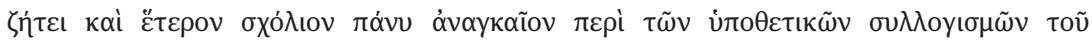

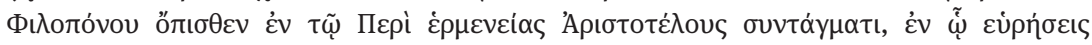

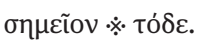

Also look above for another very necessary comment by Philoponus on the hypothetical syllogisms in Aristotle's treatise On Interpretation, in which you will find this symbol: $*$ •

The symbol can be found on fol. $13^{\mathrm{r}}$ between the lines of the text he was referring to (lines 5-6 of the main text), where the comment can be found.

\subsection{Cross-referencing manuscripts: the Princeton manuscript and the manuscript FDWM 1 of the KU Leuven Libraries, Special Collections}

Chortasmenos' exegetic activity on the Princeton manuscript also goes beyond the boundaries of this very manuscript. He actually added cross-references between the lines of Prior Analytics, Posterior Analytics and Topics by inserting a progressive numbering in red ink. As Nikos Agiotis first acknowledged (2016, 436-437), these numbers should be interpreted as cross-references to another manuscript.

In order to illustrate this practice with an example, let us turn to the beginning of the aforementioned sentence of the Posterior Analytics (see above, p. 197). In the Princeton manuscript, we read the numeral $\xi \theta^{\prime}$, i.e. '69' (see Fig. 2, 
line 5). Chortasmenos also wrote a personal remark in red ink in the right

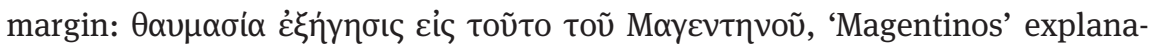
tion of this passage is marvellous'. Furthermore, a similar remark by Chortasmenos can also be seen between the name of Philoponus and the com-

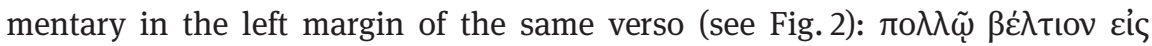

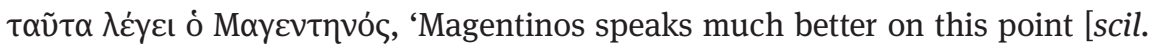
than Philoponus does]'. However, no trace of Magentinos' interpretation can be found on this particular folio of the Princeton manuscript. The cross-reference points to another manuscript, now fragmentarily preserved at the KU Leuven University Library (Special Collections, FDWM 1). ${ }^{35}$

The Leuven manuscript is composed of seven dossiers written by Chortasmenos himself plus three flying leaves originally belonging to older manuscripts. As Agiotis has pointed out $(2016,437)$, 'the seventh and last dossier [...] contains half of the missing folio of the Analytica posteriora in Princeton MS 173 [between fols 81-82]'. As for the other two leaves, I was able to identify that they belong to the manuscript Paris, BnF, gr. 1845 (thirteenth century). ${ }^{36}$ On the other hand, a leaf from the Leuven manuscript was found in the Princeton manuscript (now MS 173A). ${ }^{37}$ Both the Leuven and the Princeton manuscript were kept in the library of the Seminario Arcivescovile in Siena until 1971, where this accident may have taken place. ${ }^{38}$ As for the core of the Leuven dossiers,

35 The manuscript was acquired in 1990 by the De Wulf-Mansion Centre of the KU Leuven. The first accurate description of the content is in Cacouros 1996. See also Agiotis 2016, 436-439. On the relationship between the Leuven and the Princeton manuscripts, see Kotzabassi 2002, 56-57 n. 21; see also Cacouros 2017-2018, 91-93. The manuscript is digitized: <http://depot.lias.be:80/ delivery/DeliveryManagerServlet?dps_pid=IE3499721> (accessed on 31 July 2018).

36 This manuscript transmits the Organon as well: see the description by D. Reinsch in CAGB online: <https://cagb-db.bbaw.de/handschriften/handschrift.xql?id=51471> (accessed on 30 Jan. 2018). It can be consulted online: <https://gallica.bnf.fr/ark:/12148/btv1b107218100> (accessed on 23 Oct. 2018).

37 See Kotzabassi and Patterson Ševčenko 2010, 150. See also Kotzabassi 2002, 59: ‘[...] a separate paper leaf laid in but not bound between folios 115 and 116. [...] This loose folio is a piece of Western paper [...] with a watermark dating to about 1425 . On it are written, alternatively, parts of the commentaries of Themistios and John Philoponus on the first book of Analytica posteriora. The style of the script is that of John Chortasmenos'. See also Cacouros 2019, 92-93.

38 See Kotzabassi 2002, 62; Kotzabassi and Patterson Ševčenko 2010, 149; Agiotis 2016, 437. On the other hand, the Parisinus graecus 1845 seems not to have ever been in this library. It is therefore still to clarify where the three manuscripts were the last time together and when the passages of folia from the one to the other took place. Another hypothesis has been advanced by Cacouros 2019, 91-92, who has suggested that Chortasmenos himself may have been responsible for bounding together different codicological units and single leaves from three 
these contain excerpts from different Late Antique and Byzantine commentaries 'on sections of the Analytica priora I, both books of Analytica posteriora and Topica I' (Agiotis 2016, 436). Each comment is numbered progressively in the margin using a numeral in red ink. The numbering corresponds exactly to the numbers in the Princeton manuscript. ${ }^{39}$

Concerning commentary no. 69 on Posterior Analytics, Book 2, Chapter 12, the respective passage in the Leuven manuscript can be read in Dossier IV, fol. $6^{\mathrm{v}}$, line 19-28 (Fig. 4). ${ }^{40}$ The text corresponds to a quite extensive explanation taken from the commentary attributed to Philoponus, but actually written by Magentinos, as the Leuven manuscript confirms in this case. The comment reads as follows: $:^{41}$

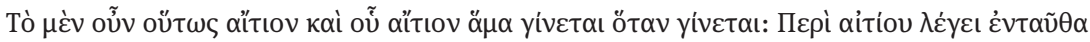

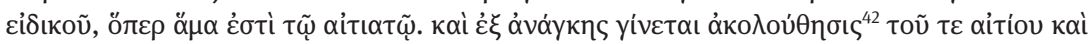

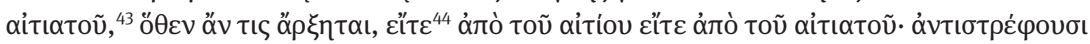

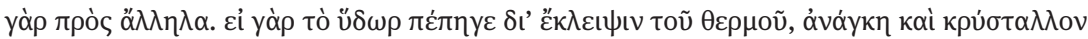

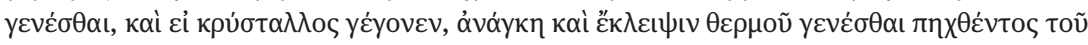

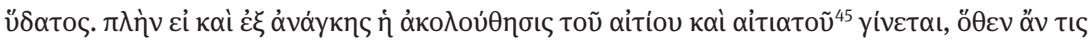

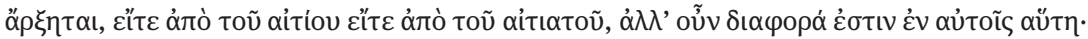

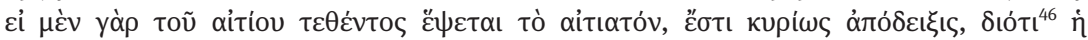

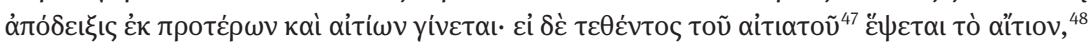

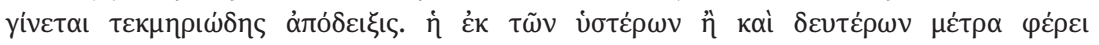

manuscripts possibly preserved in the monastery of St John Prodromos ('the Forerunner') in the district of Petra in Constantinople.

39 See Agiotis 2016, 437.

40 See Cacouros 1996, 95.

41 Wallies 1909, 386.20-387.5. In the footnotes to the Greek text, I account for variant readings of the manuscripts as reported by Wallies in his edition of the text: Paris, BnF, Coisl. 157 (siglum E, fiftheenth century), Paris, BnF, Coisl. 167 (C, fourtheenth century) and Paris, BnF, gr. 1972 (F, fourtheenth century). He also refers to the first printed edition of the Greek text in the Aldine Presse (Venice 1534, second edition): see Wallies 1909, VI-VII. In the Leuven manuscript, the numeral, lemma and first letter of the explanation are rubricated.

$42 \dot{\eta}$ ák- codd.; only the Aldina and the Lovaniensis omit the article.

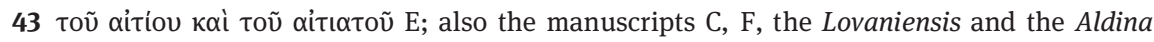
omit the second $\tau$ oṽ. The Lovaniensis has the particle $\tau \varepsilon$ as well.

44 n̆youv عlı codd.; the Aldina and the Lovaniensis omit the particle ñyouv, a typical feature of Magentinos' style: see Ebbesen 2015, 13 with n. 4 with further literature.

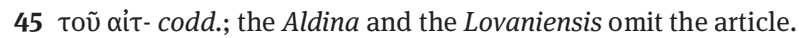

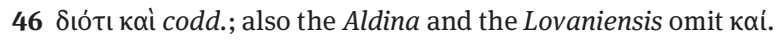

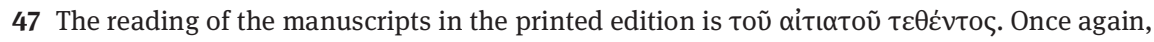
the Leuven manuscript agrees with the Aldina here.

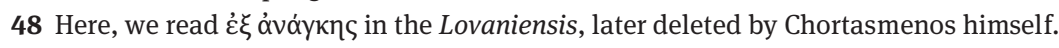




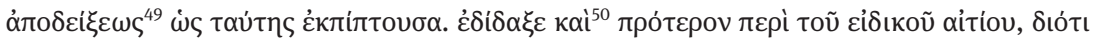

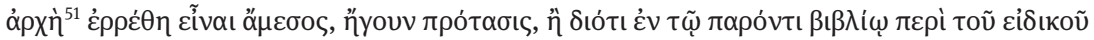

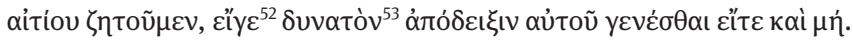

69. 'Now that which is a cause in this way and that of which it is a cause come to be at the same time'. Here he speaks about the formal [cause], which [occurs] at the same time as the effect. And there is a necessary entailment between the cause and the effect, from whichever one might begin, whether from the cause or from the effect, for they convert with each other. For if water has solidified on account of the disappearance of heat, ice too must have come to be, and if ice came to be, there must have been a disappearance of heat when the water solidified. However, even if there is a necessary entailment between the cause and the effect (from whichever one might begin, whether from the cause or from the effect), there is nonetheless this distinction [to be made] in the [two] cases. For if when the cause is posited the effect will follow, there is demonstration in the strict sense, because demonstration comes from things that are prior and are causes. But if, when the effect is posited the cause will follow, there is a sign-demonstration. The syllogism from posterior or even from secondary premises meets standards of a lower order than those of demonstration, since it falls short of being a demonstration..$^{54}$ He first taught also about the formal cause, because it was said to be an immediate principle (that is, premise), or because in the present book we are investigating about the formal cause, whether or not there can be a demonstration of it. ${ }^{55}$

The paper that Chortasmenos used in the Leuven manuscript seems to date to around the year 1425, that is, about twenty years later than the first datable record by this scholar in the Princeton manuscript. ${ }^{56}$ Therefore, it may be cautiously suggested that Chortasmenos worked with both manuscripts for decades and did not stop improving the Princeton manuscript.

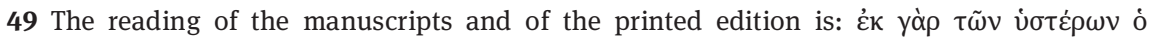

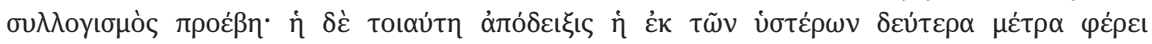

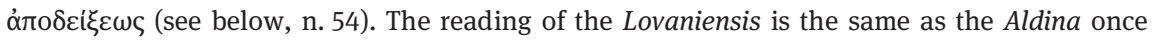
again, except for the article $\dot{\eta}$ before the preposition $\varepsilon$.

50 The Lovaniensis and the Aldina read kai against the particle $\delta \varepsilon \dot{~ o f ~ t h e ~ m a n u s c r i p t s ~ C E F . ~}$

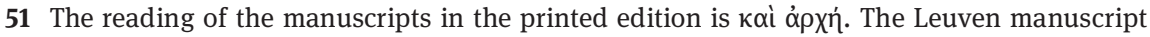

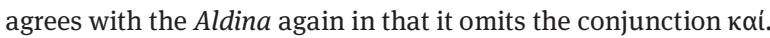

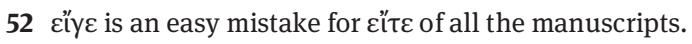

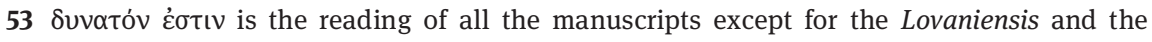
Aldina.

54 The correct reading should be 'for the syllogism proceeded from [posterior] premises. Such a demonstration which is based on posterior premises meets standards [etc.]' (transl. Goldin 2009, 79). See above, n. 49 for the Greek text.

55 I reproduce the translation by Goldin 2009, 79 but in two passages (see above, nn. 50 and 51).

56 See Kotzabassi 2002, 59 with n. 29: see above, n. 38. 
Further examples of cross-references can be found elsewhere in the Princeton manuscript, such as on fol. $114^{\mathrm{v}}$. Here Chortasmenos wrote the following note

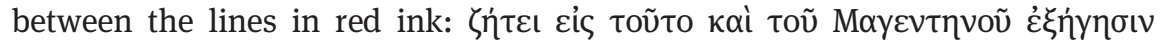

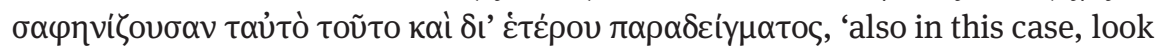
for Magentinos' explanation which also explains the very same passage by using another example'. This passage comments on Aristotle, Posterior Analytics, II 13 (97b7). The relevant comment is numbered $\sigma \theta^{\prime}$, i.e. '209'; the long explanation can be found in the Leuven manuscript in dossier IV, fol. 10v (line 39-end).

Conversely, some cross-references to the text of the Princeton manuscript can also be discovered in the Leuven manuscript. The 'parallel use of the two manuscripts' has already been pointed out by Agiotis for the first book of Posterior Analytics (2016, 437). ${ }^{57}$ To make another example from the second book, in dossier IV of the Leuven manuscript, fol. $7^{\mathrm{v}}$ (lines $7-8$ ), we read: ${ }^{58}$

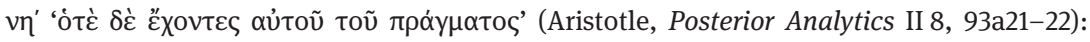

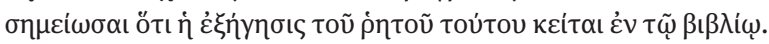

(58) 'when grasping something of the object itself' (Aristotle, Posterior Analytics II 8, 93a21-22): nota bene: the comment on this passage is in the book.

Here, the lemma taken from Posterior Analytics was commented on simply by referring to 'the book', that is, to the related book containing the main text with annotations, which is the Princeton manuscript. ${ }^{59}$ The passage can be found there on fol. $108^{\mathrm{r}}$. Chortasmenos inserted the explanation from Magentinos' commentary in the left margin (rotated 90 $).{ }^{60}$ This annotation in the Leuven manuscript is of particular importance because it reveals that Chortasmenos possibly copied the extracts from commentaries on the Aristotelian treatises after having studied and annotated the Princeton manuscript. After the production of the Leuven manuscript - or at the same time as it was being produced Chortasmenos added the cross-references to the Princeton manuscript in order to improve his manuscript of the Organon even further. Chortasmenos was

57 See also Cacouros 1996, 90.

58 The text was first published by Cacouros 1996, 95. Before the 'rediscovery' of the Princeton manuscript, Cacouros could only form the hypothesis that 'il doit s'agir de l'ancien manuscrit consulté'.

59 Elsewhere in the Leuven manuscript, Chortasmenos uses the expression 'old book' to refer to the Princeton manuscript (dossier IIIa, fol. $14^{\mathrm{v}}$ : see Agiotis 2016, 437).

60 The Greek text can be read in Wallies 1909, 367.30-368.15; the English translation is that by Goldin 2009, 56. 
therefore aware of the great value of the Princeton manuscript, which he considered essential for his learning and teaching activities. ${ }^{61}$

\section{Conclusions}

Aristotle's logical treatises were part of the standard educational curriculum of every cultivated man during the Byzantine age. Because of their complex content, students and scholars alike felt the need to supplement the manuscripts at their disposal with annotations of various kinds and from different sources. To illustrate this practice, which was quite common at the time, the manuscript Princeton MS 173 with its heavily annotated collection of four Aristotelian logical treatises offers some insights into the Byzantine exegetical practices from the thirteenth to the early fifteenth century.

The scribe who produced the manuscript at the end of the thirteenth century copied the Aristotelian treatises together with a corpus of marginal comments, which likely have already been present in his model. Later on, the annotations were constantly updated and enhanced by the various readers and owners of the manuscript. The Byzantine scholar and teacher John Chortasmenos possessed the manuscript from the very end of the fourteenth century and kept it over the first quarter of the fifteenth century, during which time he sensibly improved the exegetical apparatus. In particular, he also introduced cross-references to a separate manuscript he had produced, the manuscript FDWM 1 of the KU Leuven Libraries, Special Collections. This only contained extracts from commentaries on the treatises included in the Princeton manuscript.

The result of this multi-layered annotations is the Princeton manuscript, a sort of work-in-progress written artefact for the sake of teaching and learning in

61 Chortasmenos' study of Aristotelian Organon is also attested in other manuscripts. In fact, he composed an introductory treatise on Aristotelian logic, based upon Porphyry's Isagoge, and he collected extracts and paraphrases from Posterior Analytics and Topics. These excerpts are known thanks to two calligraphic manuscripts written by Chortasmenos himself: the manuscript Vienna, Austrian National Library (ÖNB), Supplementum graecum 75 and the manuscript Bologna, University Library, 3637: see Hunger 1969, 32f. Regarding the Bologna manuscript, see also D. Harlfinger in Moraux et al. 1976, 66-69 (an updated version is now available online: <http://cagb-db.bbaw.de/handschriften/handschrift.xql?id=9765> [accessed on 9 Sept. 2017]). Concerning the Vienna manuscript, see e.g. Hunger 1994, 124-130; Cacouros 2019, 94-96 with further bibliography. 
the context of traditional Byzantine education. This manuscript represents a valuable example of the intense exegetic activities concerning the Organon in the late Byzantine age.

\section{Acknowledgements}

This paper presents some results from the research project 'Ancient Greek manuscripts on Aristotle's works used in teaching and their interpretation' (headed by Christian Brockmann) at the Centre for the Study of Manuscript Cultures (CSMC), University of Hamburg (Sonderforschungsbereich 950 - Manuskriptkulturen in Asia, Afrika und Europa). Different parts of this paper were presented at the International Medieval Congress in Leeds (3/7/2017), at the CAGBWorkshop 'Sammeln und Edieren von Scholien zum Corpus Aristotelicum (insbes. Organon)' (Berlin, 19/1/2018) and at the conference 'L'officina del lettore: isagogi, compendi, epitomi, scolî vs. commenti' (Castellammare di Stabia University "L'Orientale", Neaples, 22/6/2018). The bibliography has been restricted to some essential works. I thank Nikos Agiotis and Christian Brockmann for their valuable suggestions on a first draft of this paper as well as Carl Carter for copy-editing the final version of this paper.

\section{Abbreviations}

$P L P$

Erich Trapp (ed.), Prosopographisches Lexikon der Palaiologenzeit, Vienna: Österreichischen Akademie der Wissenschaften, 1976-1995.

RGK Ernst Gamillscheg, Dieter Harlfinger and Herbert Hunger (eds), Repertorium der griechischen Kopisten 800-1600, I: Handschriften aus Bibliotheken Großbritanniens; II: Handschriften aus Bibliotheken Frankreichs; III: Handschriften aus Bibliotheken Roms mit dem Vatikan, Vienna: Österreichischen Akademie der Wissenschaften, 1989, 1994 and 1997.

\section{References}

Agiotis, Nikos (2016), 'A Byzantine "Portal” for Scholia on the Organon or the Use of Reference Signs and Numbers in Princeton MS. 173', in Proceedings of the 23nd International Congress of Byzantine Studies (Belgrade 22-27 August 2016). Round Tables, Belgrade: s.n., 435-439.

Barnes, Jonathan (1975), Aristotle's Posterior Analytics, Oxford: Clarendon. Barnes, Jonathan (1993), Aristotle. Posterior Analytics, second edition, Oxford: Clarendon. Barnes, Jonathan (2003), Porphyry. Introduction, Oxford: Clarendon. 
Brockmann, Christian (2020), 'Helpful interactions between commentary and text: Aristotle's Posterior Analytics and important manuscripts of this treatise', in Shari Boodts, Pieter De Leemans and Stefan Schorn (eds), Sicut dicit. Editing Ancient and Medieval Commentaries on Authoritative Texts, Turnhout: Brepols, 209-242.

Brunschwig, Jacques (ed.) (1967), Aristote, Topiques, I: Livres I-IV, Paris: Les Belles Lettres.

Bülow-Jacobsen, Adam, and Ebbesen, Sten (1982), 'Vaticanus Urbinas Graecus 35. An edition of the scholia on Aristotle's Sophistici Elenchi', Cahiers de l'Institut du Moyen-Âge Grec et Latin, 43: 45-120.

Cacouros, Michel (1996), “Un manuel de logique organisé par Jean Chortasménos et destiné à l'enseignement. Catalogage du manuscrit', Revue des études byzantines, 54: 67-106.

Cacouros, Michel (2001), 'Les schémas dans les manuscrits grecs de contenu logique: raisons d'être, fonctions et typologie', Gazette du livre médiéval, 39: 21-33.

Cacouros, Michel (2017-2018), 'Littérature philosophique à Byzance et sa postérité à l'époque moderne', Annuaire de l'École Pratique des Hautes Études. Résumés des conférences et des travaux, 150: 88-101.

Detel, Wolfgang (ed.) (1993), Aristoteles, Analytica posteriora, II/2, Berlin: Akademie Verlag.

Ebbesen, Sten (1981), Commentators and commentaries on Aristotle's Sophistici elenchi. A study of post-Aristotelian ancient and Medieval writings on fallacies, 3 vols, Leiden: Brill.

Ebbesen, Sten (2015), 'The Posterior Analytics 1100-1400 in East and West', in Joël Biard (ed.), Raison et démonstration. Les commentaires médiévaux sur les Seconds analytiques, Turnhout: Brepols, 11-30.

Erismann, Christophe (2017), 'Logic in Byzantium', in Antony Kaldellis and Niketas Siniossoglou (eds), The Cambridge Intellectual History of Byzantium, Cambridge: Cambridge University Press, 362-380.

Gielen, Erika (ed.) (2016), Nicephori Blemmydae De virtute et ascesi necnon losephi Racendytae De virtute, Leuven: Brepols.

Goldin, Owen (2009), Philoponus(?). On Aristotle Posterior Analytics 2, London: Bloomsbury.

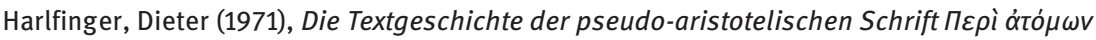

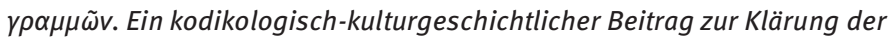
Überlieferungsverhältnisse im Corpus Aristotelicum, Amsterdam: Hakkert.

Hunger, Herbert (1969), Johannes Chortasmenos (ca.1370-ca. 1436/37). Briefe, Gedichte und kleine Schriften. Einleitung, Regesten, Prosopographie, Text, Vienna: Österreichischen Akademie der Wissenschaften.

Hunger, Herbert (1978), Die hochsprachliche profane Literatur der Byzantiner, I, Munich: Beck. Hunger, Herbert (unter Mitarb. v. Christian Hannick) (1994), Katalog der griechischen Handschriften der Österreichischen Nationalbibliothek, IV: Supplementum Graecum, Vienna: Brüder Hollinek.

Kotzabassi, Sofia (2002), 'Aristotle's Organon and Its Byzantine Commentators', Princeton University Library Chronicle, 65: 51-62 (+ 2 Plates).

Kotzabassi, Sofia and Nancy Patterson Ševčenko, (2010), Greek Manuscripts at Princeton, Sixth to Nineteenth Century. A Descriptive Catalogue, Princeton: Princeton University Press.

Malink, Mario (2011), 'Organon', in Christoph Rapp and Klaus Corcilius (eds), Aristoteles Handbuch. Leben - Werk - Wirkung, Stuttgart/Weimar: J.B. Metzler, 65-74.

Moraux, Paul, Dieter Harlfinger, Diether Reinsch, and Jürgen Wiesner (1976), Aristoteles Graecus. Die griechischen Handschriften des Aristoteles, I. Alexandrien - London, Berlin: De Gruyter.

Oehler, Klaus (1964), 'Aristotle in Byzantium', Greek, Roman and Byzantine Studies, 5: 133-146. 
Panizza, Letizia (1999), 'Learning the syllogisms: Byzantine visual aids in Renaissance Italy Ermolao Barbaro (1543-93) and others', in Constance Blackwell and Sachiko Kusukawa (eds), Philosophy in the Sixteenth and Seventeenth Centuries. Conversations with Aristotle, Aldeshort: Ashgate, 22-47.

Prapa, Christina (2012), 'Diagramme in der Handschriftentradition. Ein methodologischer Beitrag anhand der Überlieferungsgeschichte von Aristoteles, De Caelo', Codices manuscripti, 82-83: 31-41.

Rambourg, Camille (2012), 'Les diagrammes syllogistiques des scholies de Stephanos à la Rhétorique d'Aristote (CAG 21.2)', Classica et mediaevalia, 63: 279-315.

Ross, William D. (ed.) (1949), Aristotle's Prior and Posterior Analytics. A revised text with introduction and commentary, Oxford: Clarendon.

Smith, Robin (ed.) (1997), Aristotle, Topics. Books I and VIII with excerpts from related texts, Oxford: Clarendon.

Valente, Stefano (2021): 'Between commentary, glosses and marginal notes: some manuscript practices for commenting Aristotle's Posterior Analytics in the twelfth century', in Tommaso Raiola (ed.), Nell'officina del lettore. Studi per Ivan Garofalo, Pisa: Fabrizio Serra, forthcoming.

Wallies, Maximilian (ed.) (1909), Ioannis Philoponi In Aristotelis Analytica posteriora commentaria cum Anonymo in librum II, Berlin: Reimer. 


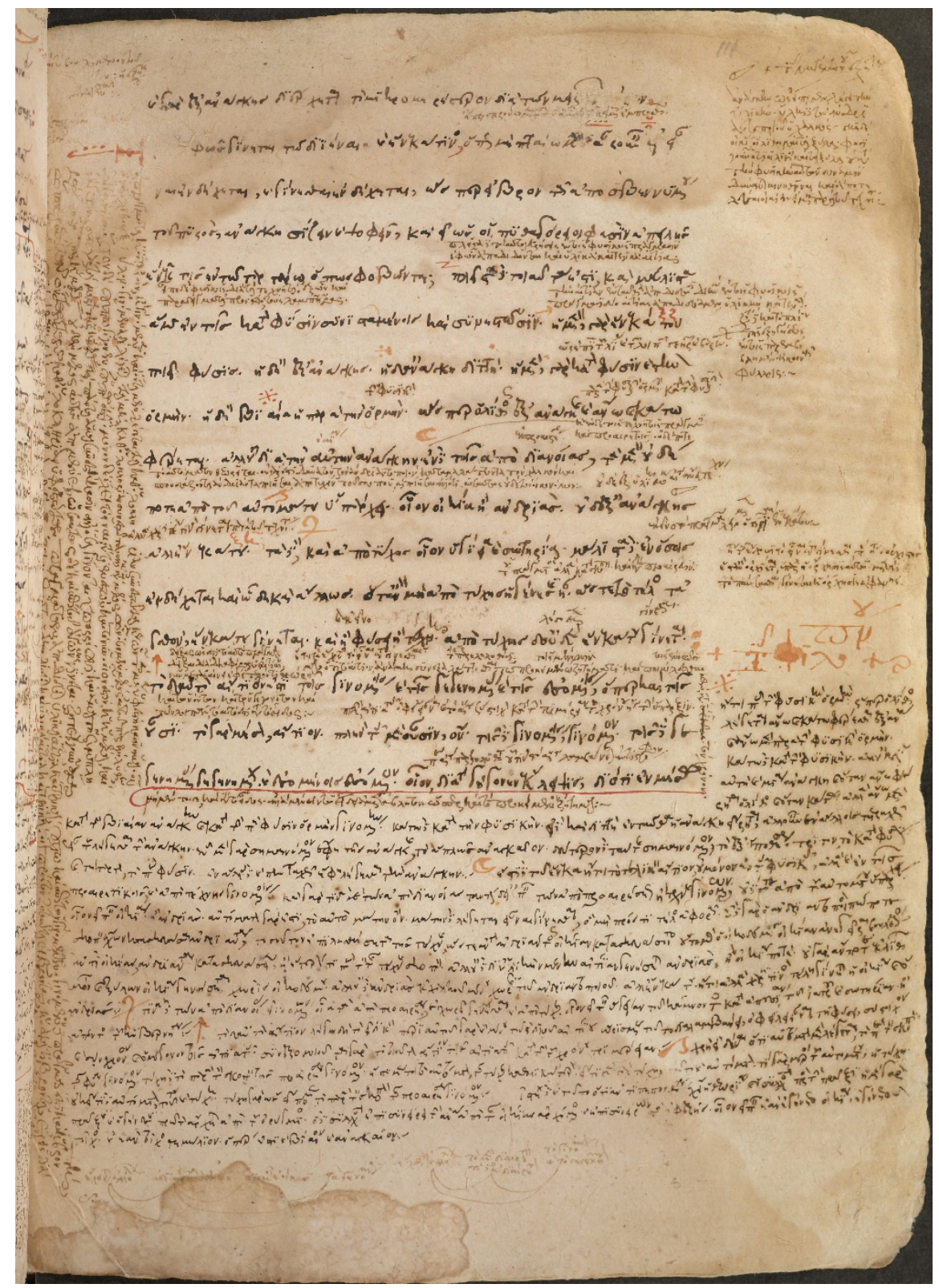

Fig. 1: Princeton, University Library, MS 173, fol. 111' ; courtesy of Princeton University Library. 
y

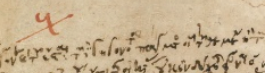

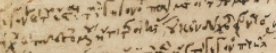
X

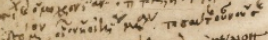

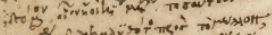

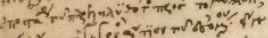

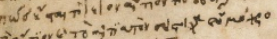

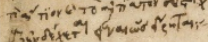

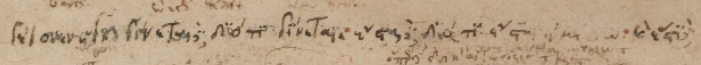

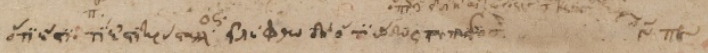

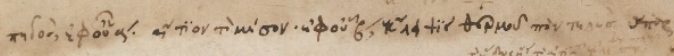

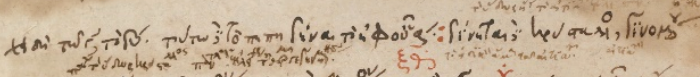

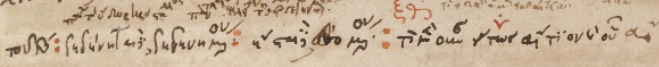

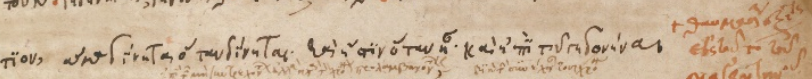

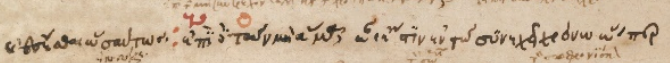
mess $\sin ^{4}$

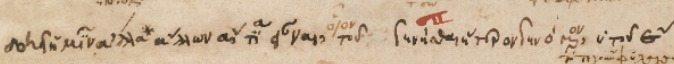

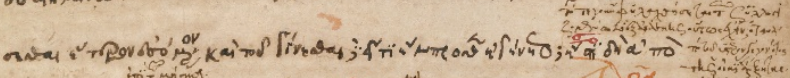

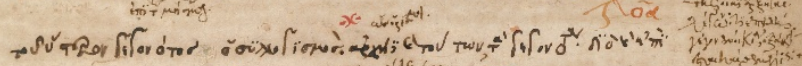

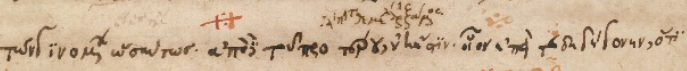

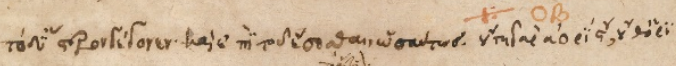

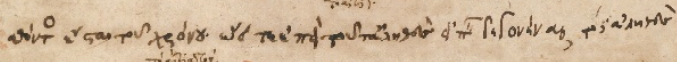

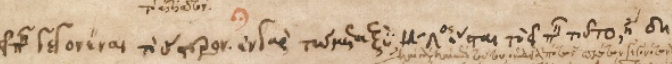

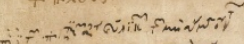

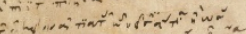

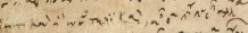

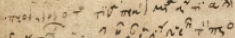
- The

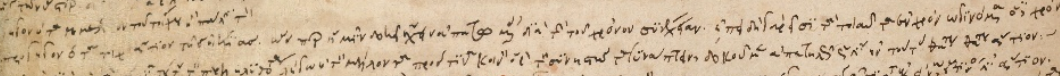

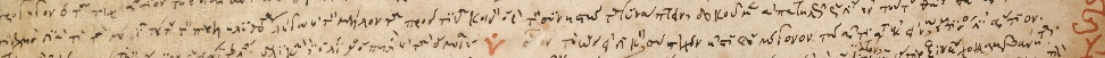

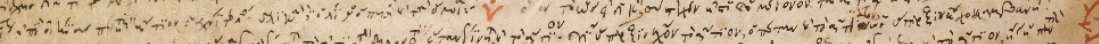

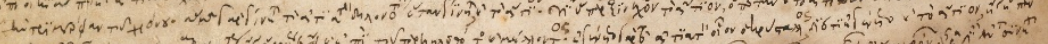

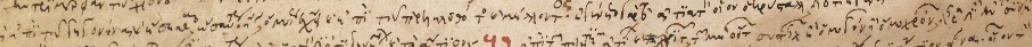

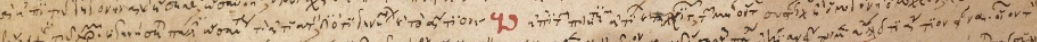
iw

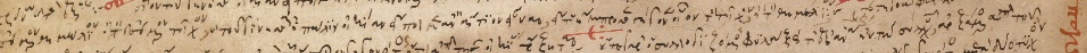

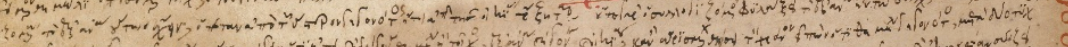

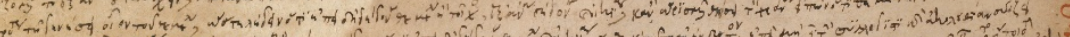

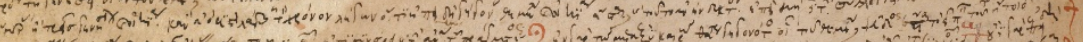

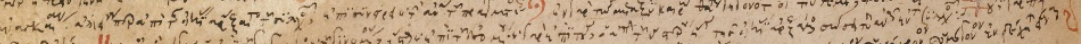

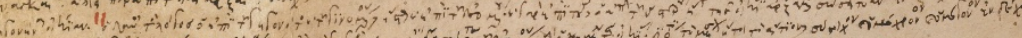

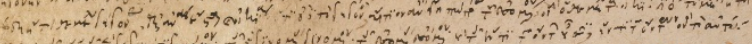

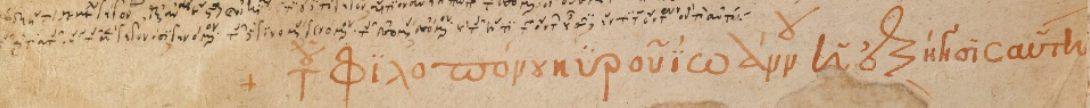

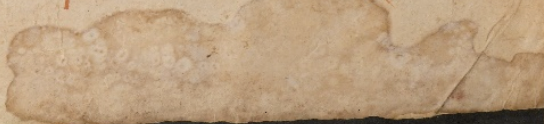

Fig. 2: Princeton, University Library, MS 173, fol. $111^{\vee}$; courtesy of Princeton University Library. 


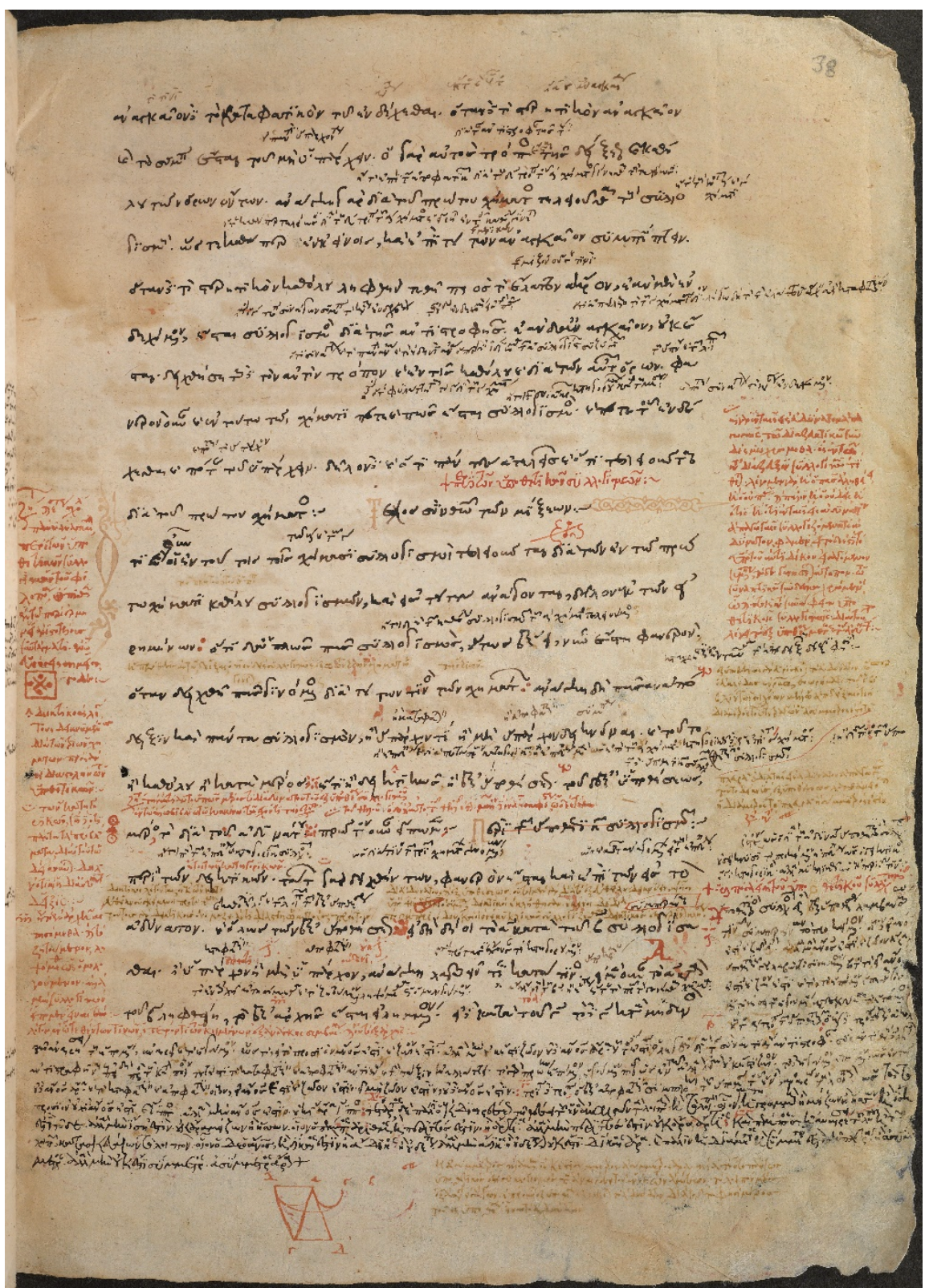

Fig. 3: Princeton, University Library, MS 173, fol. $38^{\text {r}}$; courtesy of Princeton University Library. 


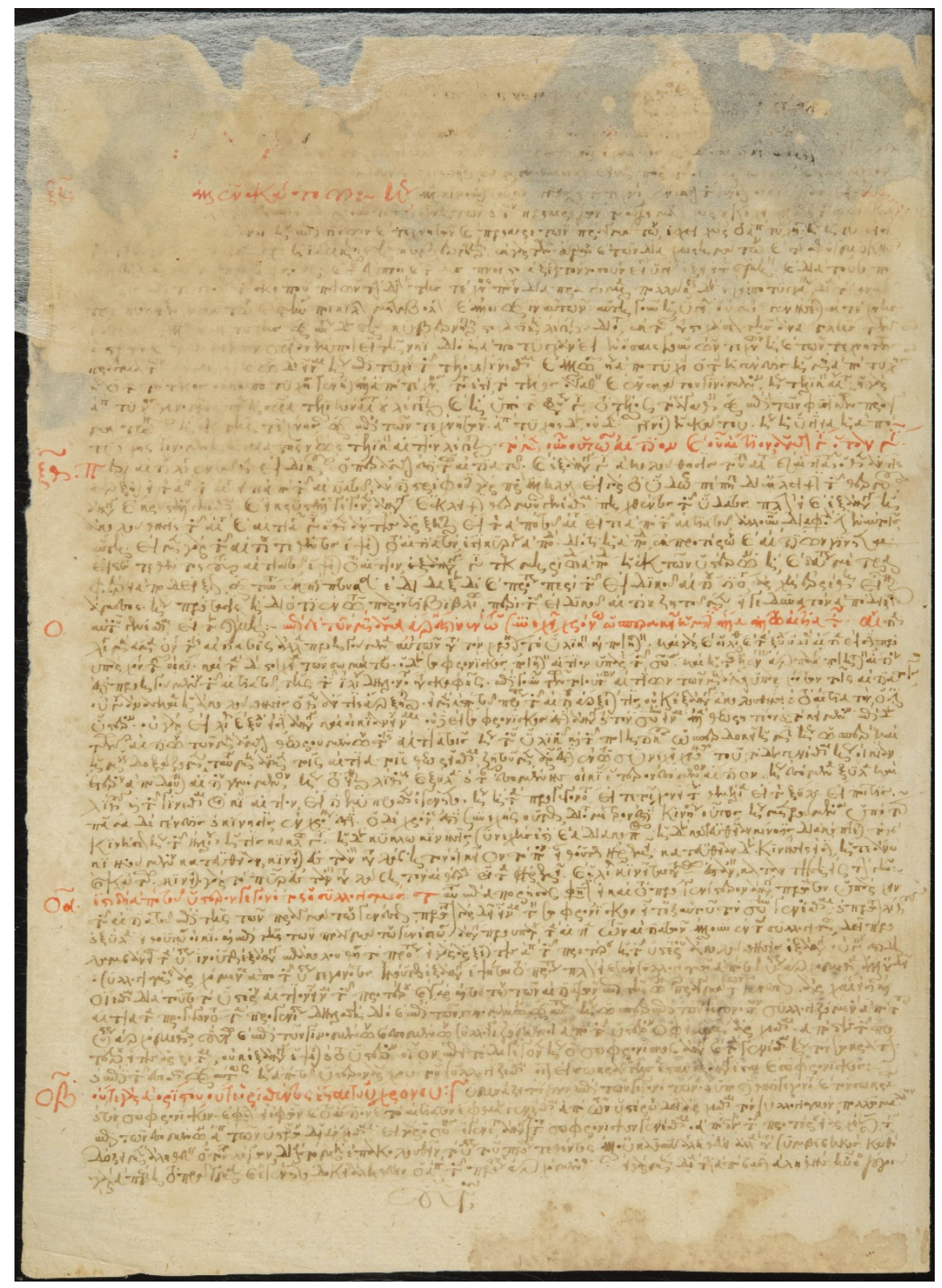

Fig. 4: Leuven, KU Leuven Libraries, Special Collections, FDWM 1, dossier IV, fol. 8; ; 